\title{
Health risk assessment of environmental selenium: Emerging evidence and challenges (Review)
}

\author{
MARCO VINCETI $^{1,2}$, TOMMASO FILIPPINI ${ }^{1,2}$, SILVIA CILLONI $^{1,2}$, ANNALISA BARGELLINI $^{1,2}$, \\ ANNA VALERIA VERGONI ${ }^{2}$, ARISTIDES TSATSAKIS ${ }^{3}$ and MARGHERITA FERRANTE ${ }^{4}$ \\ ${ }^{1}$ CREAGEN, Research Center of Environmental, Genetic and Nutritional Epidemiology, Section of Public Health, \\ and ${ }^{2}$ Department of Biomedical, Metabolic and Neural Sciences, University of Modena and Reggio Emilia, \\ Modena, Italy; ${ }^{3}$ Department of Forensic Sciences and Toxicology, University of Crete, Heraklion, Crete, Greece; \\ ${ }^{4}$ Department of Medical, Surgical Sciences and Advanced Technologies 'G.F. Ingrassia', University of Catania, Catania, Italy
}

Received January 2, 2017; Accepted February 20, 2017

DOI: $10.3892 / \mathrm{mmr} .2017 .6377$

\begin{abstract}
New data have been accumulated in the scientific literature in recent years which allow a more adequate risk assessment of selenium with reference to human health. This new evidence comes from environmental studies, carried out in populations characterized by abnormally high or low selenium intakes, and from high-quality and large randomized controlled trials with selenium recently carried out in the US and in other countries. These trials have consistently shown no beneficial effect on cancer and cardiovascular risk, and have yielded indications of unexpected toxic effects of selenium exposure. Overall, these studies indicate that the minimal amount of environmental selenium which is source of risk to human health is much lower than anticipated on the basis of older studies, since toxic effects were shown at levels of intake as low as around $260 \mu \mathrm{g} /$ day for organic selenium and around $16 \mu \mathrm{g} /$ day for inorganic selenium. Conversely, populations with average selenium intake of less than 13-19 $\mu \mathrm{g}$ /day appear to be at risk of a severe cardiomyopathy, Keshan disease. Overall, there is the need to reconsider the selenium standards for dietary intake, drinking water, outdoor and indoor air levels, taking into account the recently discovered adverse health effects of low-dose selenium overexposure, and carefully assessing the significance of selenium-induced proteomic changes.
\end{abstract}

Correspondence to: Dr Marco Vinceti, CREAGEN, Environmental, Genetic and Nutritional Epidemiology Research Center, Section of Public Health, Department of Biomedical, Metabolic and Neural Sciences, University of Modena and Reggio Emilia, Via Campi 287, I-41125 Modena, Italy

E-mail: marco.vinceti@unimore.it

Key words: selenium, risk assessment, environment, epidemiology, biochemistry

\section{Contents}

1. Introduction

2. The epidemiologic evidence

3. Adequacy of environmental standards

\section{Introduction}

The health risk assessment of environmental selenium, concerning both abnormally low and high intakes, and the related regulatory guidelines are generally based on 'old' evidence, since they have generally been unable to take into consideration the most recent epidemiologic and biochemical evidence, and particularly the recent results of large and well-designed randomized controlled trials (RCTs) (1-3). The results of these trials, in connection with biochemical and toxicological studies, have shed new light on this relevant public health issue. This has happened with reference to both the upper and the lower limits of selenium intake, which have been so far based in all the assessment on observational studies carried out in seleniferous Chinese areas during the 1980s $(4,5)$. The availability of the experimental studies (the trials) is of particular importance, since they allowed to rule out the key issue of (unmeasured) confounding, typically affecting most of observational studies with the possible only exception of the so called 'natural experiments' (6). In addition, the recent observational and experimental studies made it possible to investigate different populations with reference to age, genetic background and life-style factors, also allowing to test the health effect of selective exposure to specific selenium compounds, such as inorganic haxavalent selenium (selenate) and an organic form, selenomethionine. This is particularly important since there is growing evidence of the key importance of the specific selenium forms in influencing the biological activity of this element, with reference to both its toxicological and nutritional effects (7-11).

\section{The epidemiologic evidence}

A very large number of epidemiologic studies assessed the relation between chronic exposure to environmental selenium 


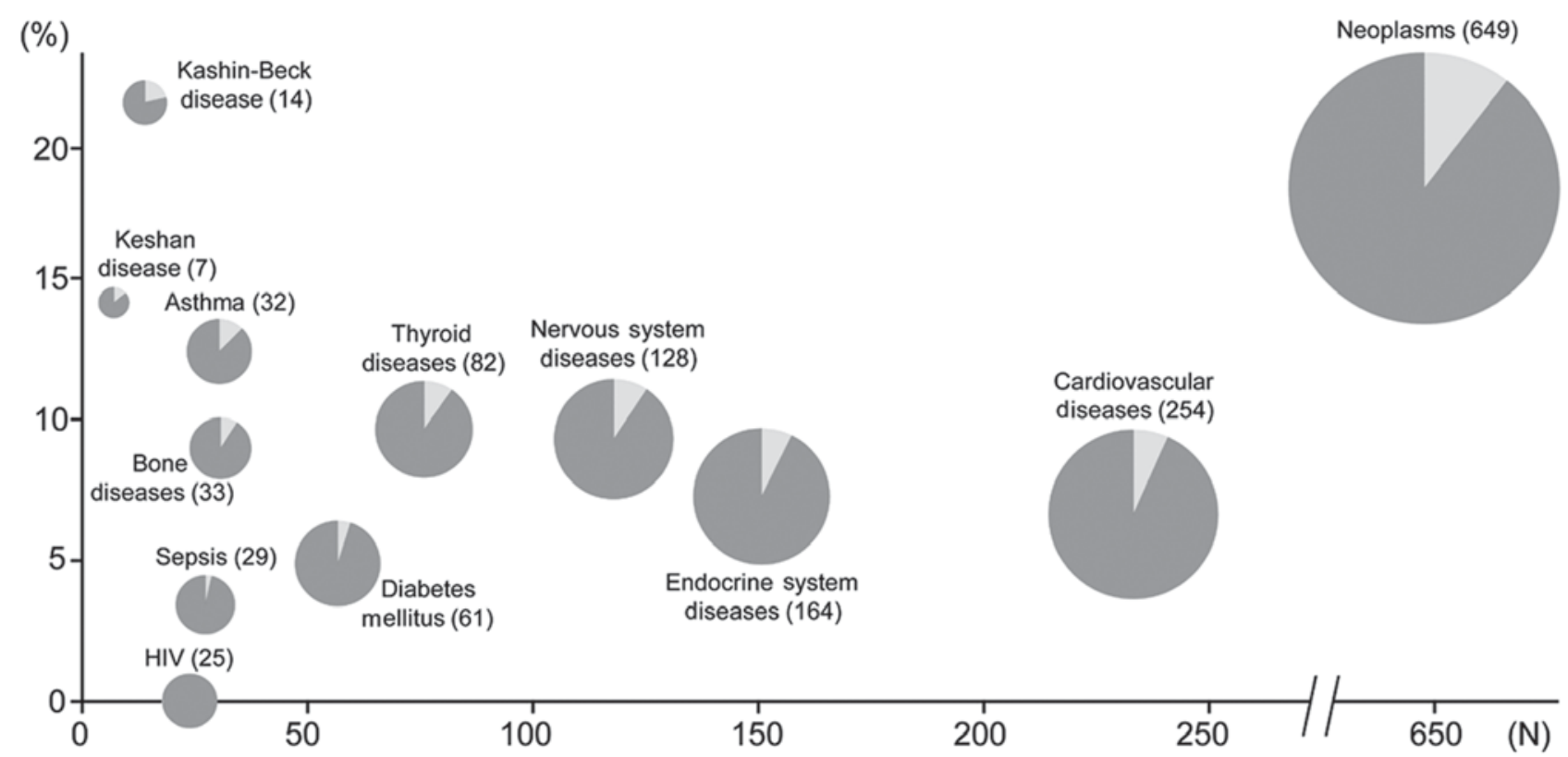

Figure 1. Number of hits (on the horizontal axis) generated by PubMed search on January 4, 2017 with the MeSH terms 'selenium' and 'humans' and ('epidemiology' or 'epidemiologic methods') linked to specific diseases (dark plus light gray areas). Those additionally linked with the additional MeSH terms 'environment' or 'risk' or 'assessment and government regulation' are in light gray (percentage on the total hits on the vertical axis).

and human health. The studies on this issue frequently investigated the effect on human health of unusually low or high environmental exposures to selenium, due to an abnormal selenium content in soil, locally produced foods and drinking water, or following combustion of coal with high selenium content $(5,12,13)$. In addition, the scientific literature encompasses a large number of nutritional epidemiology studies on the long-term health effects of selenium carried out in populations living in non-seleniferous regions and countries. These studies include experimental investigations (randomized controlled trials) and observational studies, the latter characterized by case-control, cohort, cross-sectional and ecologic design and being characterized by a far weaker ability compared with trials in addressing the selenium and health relation $(1,14,15)$. While the entire review of this huge literature goes beyond the possibility of this report, we aim at briefly updating the evidence generated by the most recent environmental and nutritional studies on the human health effects of selenium, the biological plausibility of this relation, an overview of the challenges that these studies and their interpretation pose, and finally their implications on the adequacy of current environmental selenium standards. Our update of this issue starts from the comprehensive assessments of selenium exposure carried out by the US Institute of Medicine in 2000 (4) and by a World Health Organization (WHO) working group in 2004 (16).

Studies in populations living in unusually high and low selenium environments. A large number of environmental studies which investigated the health effects of unusually high or low selenium areas have been published, as summarized in Table I. These studies have also substantially contributed to the PubMedindexed papers on the epidemiology of selenium and human health in addition to the previous papers (Fig. 1), adding relevant data to our understanding of the health effects of selenium in humans. Some of these studies have been published after the 2000 Institute of Medicine selenium assessment (4), considerably extending the limited evidence previously available on the basis of a few 'old' Chinese studies. This literature includes the investigation of health effects of high-selenium environment in South and North America, India, China, and Italy. The high content of selenium in these areas, in most cases of geological origin, has induced unusually high levels of selenium in locally grown foodstuffs and occasionally in outdoor air and in drinking water, thus increasing human exposure to the element. However, systematic investigations of the health effects of such exposures are unfortunately limited, and in most cases they came from cross-sectional studies, and very rarely from studies with a more adequate design, such as case-control and particularly cohort studies. In addition, the observational design of these studies induces in most cases a major concern, the potential bias arising from unmeasured (dietary and life-style) confounding, in addition to the potential issue of exposure misclassification. Moreover, health endpoints were generally different in these studies, thus not allowing their systematic analysis (and meta-analysis) in the different populations. Finally, in several cases the small number of exposed subjects made it impossible to compute statistically stable estimates, and this lack of precision hampered the detection of potential health effects of such abnormally low and high exposures to environmental selenium.

Overall, these studies have yielded an indication that the extremely low selenium intake, in the order of $<10-15 \mu \mathrm{g} /$ day, may increase the risk of a severe cardiomyopathy named 'Keshan disease' (17-20), while high selenium intake may have unfavorable effects on the endocrine system and particularly on the thyroid status (21), and increase the risk of type 2 diabetes $(3,22,23)$, some specific cancers such as melanoma and lymphoid cancers (24-26), and nervous system disturbances including alterations in visual evoked potentials (27) and excess risk of amyotrophic lateral sclerosis $(26,28)$. 
Table I. Overview of studies on the health effects of environmental selenium.

A, Studies published up to 2000

\begin{tabular}{|c|c|c|}
\hline Area & Population study & Laboratory indications \\
\hline $\begin{array}{l}\text { Colorado } \\
\text { Tsongas } 1977 \\
\text { and } 1978(99,100)\end{array}$ & $\begin{array}{l}\text { A community of } 120 \text { households } \\
\text { receive tap water containing } \\
\text { unusually high Se levels } \\
\text { ( } 50-125 \mu \mathrm{g} / \mathrm{l}) \text {. Eighty-six } \\
\text { persons participate in this study. }\end{array}$ & $\begin{array}{l}\text { Higher urinary levels of Se } \\
\text { in the exposed group. } \\
\text { Much higher urinary Se } \\
\text { levels of women with a } \\
\text { history of miscarriage. }\end{array}$ \\
\hline
\end{tabular}

Mianning,

Sichuan Province,

China

Keshan Disease

Research Group

of the Chinese

Academy of

Medical Sciences,

Bejing 1979 (18)

Milan, New

Mexico

Valentine 1980,

1988 and 1997

(101-103)

Enshi, Hubei

Province, China

Yang 1983 (55)

Red Butte and Jade Hills in

Wyoming and

Grants in New

Mexico

Valentine 1987

(104)

South Dakota and Wyoming

Longnecker

1991 (105)
This study was carried out among

children of susceptible age

(1-9 years) in 1974 and 1975.

One half of the children were

given sodium selenite and the

other half placebo. The

subjects took sodium selenite

once a week, the dosage being

1-5 year old $0.5 \mathrm{mg}, 6-9$ year old

$1.0 \mathrm{mg}$ and above 11 years $2.0 \mathrm{mg}$.

In 1976-1977 all the subjects

were given sodium selenite,

no controls were used.

Thirty-three residents in a small community consumed drinking water from personal wells containing very high levels of Se (26-1800 $\mu \mathrm{g} / \mathrm{l})$.

Endemic disease in 1961 in parts of the population of Enshi county. During 1961-1964, the morbidity was almost $50 \%$ in the 248 inhabitants of the most affected villages.

Daily dietary intake of $\mathrm{Se}$ of $4.99 \mathrm{mg}$.

Fifty residents in three communities with unusually high Se content in their drinking water supply systems (respectively 494, 194, $327 \mu \mathrm{g} / 1)$ were compared to 99 individuals from Nevada and Wyoming communities which had drinking water with 3 and $2 \mu \mathrm{g} / 1 \mathrm{Se}$, respectively.

Inhabitants (142) of areas with endemic Se overexposure recruited over a 2-year period. About half of the 142 free-living subjects had selenium intake greater than $200 \mu \mathrm{g} /$ day.
Not assessed.

High Se exposure through

drinking water was

associated with lower

blood glutathione

peroxidase activity.

In high Se area of chronic selenosis, hair Se level was $32.2 \mu \mathrm{g} / \mathrm{g}$ and blood Se level was $3.2 \mu \mathrm{g} / \mathrm{ml}$.

Blood and hair Se levels were higher in exposed subjects but the differences were small despite the large difference in water Se levels. Differences in urine Se concentrations between exposed and unexposed subjects were much larger, though still less marked than the difference in water Se content.

Se levels assessed using whole blood, serum, toenail, urine and dietary intake.
No significant differences between exposed and unexposed groups. Lack of association between spontaneous abortion and $\mathrm{Se}$ exposure through drinking water in women experiencing miscarriages in that community.

In 1974 , there were $13.5 \%$ cases of Keshan disease among control group, while only $2.2 \%$ subjects fell ill in the Se supplemented group. In 1975 , there were $9.5 \%$ cases of Keshan disease in the control group, while only $1.0 \%$ cases in the treated group. In 1976 and 1977 there were respectively $0.32 \%$ and 0 cases of Keshan disease among treated subjects.

Not assessed.

The tissues most affected during the time of heavy prevalence were loss of hair and nails, skin lesions, tooth decay and abnormalities of the nervous system like peripheral anesthesia, acroparaesthesia and pain in the extremities.

Little evidence of a relation between Se exposure and risk for a number of gastrointestinal, cutaneous and nervous system conditions emerged.

Higher prevalence of diarrhea, neurological diseases in the most exposed communities of Grants and Red Butte.

No effect of Se exposure on the risk of paresthesias was found (it actually decreased). By contrast, an increased risk of lethargy emerged since the OR of having this sign more frequently than the median for an increase of one standard deviation of whole blood, toenails or dietary Se was equal to $1.41,1.41$ and 1.43 respectively. 
Table I. Continued.

A, Studies published up to 2000

\begin{tabular}{|c|c|c|c|}
\hline Area & Population study & Laboratory indications & Health effects \\
\hline $\begin{array}{l}\text { Portoguesa, } \\
\text { Venezuela } \\
\text { Brätter } 1996 \\
(106)\end{array}$ & $\begin{array}{l}\text { Sixty-five mothers living in three } \\
\text { regions of different dietary Se } \\
\text { intake level were examined. } \\
\text { The range of dietary Se range in } \\
\text { the Venezuelan seleniferous areas } \\
\text { is } 250-980 \mu \mathrm{g} / \text { day. }\end{array}$ & $\begin{array}{l}\text { Mean serum TSH, thyroxin } \\
\text { and tri-iodo-thyronine were } \\
\text { in the normal range. Strong } \\
\text { regional differences for serum } \\
\text { Se and } \mathrm{FT}_{3} \text {, but no effect } \\
\text { on the } \mathrm{TSH} \text { and } \mathrm{FT}_{4} \text { levels. }\end{array}$ & $\begin{array}{l}\text { Long-term high dietary Se supply } \\
\text { on the } \mathrm{FT}_{3} \text { level in serum is } \\
\text { associated with the depression in } \\
\text { the activity of the selenoenzyme } \\
\text { iodo-thyronine-deiodinase ( } 5 \mathrm{DI} \text { ), } \\
\text { which catalyzes the production } \\
\text { of } \mathrm{T}_{3} \text { from } \mathrm{T}_{4} \text {. }\end{array}$ \\
\hline
\end{tabular}

B, Studies published after 2000

Enshi, Hubei

Province, China

Fordyce 2000

(107)

Yu Tang Ba,

Hubei Province,

China

Zhu 2001 (108)

Punjab, India

Hira 2003 (109)

Nunavik,

Northern

Quebec, Canada

Saint-Amour

2006 (27)

\section{Fifteen villages from $3 \mathrm{Se}$} environments in Enshi district were investigated. Soil, grain, drinking water and human hair samples were collected from 5 Low-Se-Keshan-Disease villages (LK), 5 High-Se-Notoxicity (HN) villages, and 5 High-Se-Toxicity (HT) villages.

Se was mainly present in the carbonaceous shale (stone coal) of this area.

Eighty subjects living in a seleniferous area compared to 80 controls living in non-seleniferous area. Se intake in the endemic area was $632 \pm 31.2 \mu \mathrm{g} /$ day in men and $475 \pm 52.8 \mu \mathrm{g} /$ day in women

One hundred and two Canadian Inuit children aged 5-6 years are involved in this study. The high consumption of fish and marine mammals by this population was associated to an unusually high intake of polychlorinated biphenyls, methyl-Hg, $\mathrm{Se}$ and other potentially neurotoxic substances.

Lower Tapajos River region (Parà state), Brazil

Lemire 2011

and 2012

$(110,111)$
In the $5 \mathrm{HT}$ villages were higher Se levels than $\mathrm{NH}$ villages, with geometric mean of Se in soil of $9.46 \mu \mathrm{g} / \mathrm{g}$, in water of $32.6 \mu \mathrm{g} / \mathrm{l}$ and in the hair of $26.4 \mu \mathrm{g} / \mathrm{g}$.

In 1999 , Se in soil was $4.75 \pm 7.43 \mathrm{mg} / \mathrm{kg}$. Se in stream water was $58.4 \pm 16.8 \mu \mathrm{g} / \mathrm{l}$.

Concentration of Se in the hair, nails and urine samples in the study group were higher than control group.

The average blood Se concentration observed in the present study was about $5.6 \mathrm{mmol} / 1$. Moreover, close to $20 \%$ of the children tested had blood Se concentrations exceeding the maximum safe level recommended for adults, which was from 8 to $10 \mathrm{mmol} / \mathrm{l}$. Se umbilical blood level was $429 \mu \mathrm{g} / \mathrm{l}$.

Median plasma Se level was $135 \mu \mathrm{g} / 1$. A direct association between Se plasma levels and motor performance was found.
Despite the high concentrations of Se found in the population of the HN and HT villages, no incidence of selenosis have been reported in recent years in Enshi District.

Few people living in this area experienced loss of hair and nails from early $1930 \mathrm{~s}$

to 1961 . In 1963,19 of 23

local inhabitants manifested symptoms of Se poisoning.

$17.5 \%$ of men and $15 \%$ of women showed loss of hair and other $\mathrm{Se}$ related symptoms like tooth decay or black teeth.

Neurotoxic signs, i.e. alterations in visual evoked potentials with the induction of longer latency of some of these parameters.

These results appeared to disprove the detrimental effect of $\mathrm{Se}$ exposure on motor exposure on motor functions, but could also be due to confounding such as unmeasured heavy metals and other chemicals. 
Table I. Continued.

B, Studies published after 2000

\begin{tabular}{lll}
\hline Area & Population study & Laboratory indications \\
\hline
\end{tabular}

Shaanxi Seventy-one Keshan disease

Province, $\quad$ (KD) patients were compared

China

Lei 2011 (20) to 78 controls from the same endemic area and 212 external healthy controls from a non-endemic area.

Enshi, Hubei Province, China Qin 2013 (112)

Reggio Emilia, Northern Italy Vinceti 2013 and $2016(5,26)$

Outbreak of human selenium The calculated daily intake of Se was $2144 \mu \mathrm{g} /$ day, cereal followed by vegetables, meats and drinking water.

\section{From 1974 to 1985,2065}

municipal residents consumed drinking water with high Se content approaching the poisoning in the early 1960 s. Se-rich carbonaceous rock was responsible for high-Se content in soils, crops, water and thus human Se poisoning. consumption is the major pathway of Se intake for local residents, European standard of $10 \mu \mathrm{g} / \mathrm{l}$ in its inorganic hexavalent form (selenate).

Macapà (Amapà state) and Belem (Parà state), Brazil Martens 2015 (113)

Punjab, India Chawla 2016 (114)
Forty-one preschool children from Macapà and 88 preschool from Belem were enrolled. The Brazilian Amazon region is considered to have particularly Se-rich soil. Brazil nuts are often used as a strategy to improve Se status in Se-deficient populations. This study investigated Se intake and Se status of children from Macapà who received a Brazil nut-enriched diet and compared with children from Belem where Brazil nut supplementation did not occur. Mean Se intake in Macapà diet: 155.30 (range: 98.70-195.30) $\mu \mathrm{g} /$ day.

Human subjects (650) living in a seleniferous area compared to 50 healty controls from a village in a non-seleniferous area.
Blood selenium level was $0.065 \pm 0.016 \mu \mathrm{g} / \mathrm{ml}$ in

$\mathrm{KD}$ patients and $0.086 \pm 0.020 \mu \mathrm{g} / \mathrm{ml}$ in controls. GPx-1 activity was $73.002 \pm 12.623 \mathrm{U} / \mathrm{g} \mathrm{Hb}$ ) in $\mathrm{KD}$ patients and 106.402 $\pm 24.268 \mathrm{U} / \mathrm{g} \mathrm{Hb}$ ) in controls.

Blood Se was $3248 \mu \mathrm{g} / \mathrm{l}$.

Not assessed.

Children from Belem presented adequate plasma and erythrocytes levels, whereas the Macapà group had higher levels. Also nails and hair were more elevated in children from Macapà.

Hair Se were 50.9 $\pm 58.0 \mu \mathrm{g} / \mathrm{g}$ in the exposed group compared to $22.5 \pm 10.7 \mu \mathrm{g} / \mathrm{g}$ in controls. Corresponding Se levels (mean-SD) in nail clippings in the study and control groups were $154.0 \pm 91.5 \mu \mathrm{g} / \mathrm{g}$ and $117.4 \pm 49.8 \mu \mathrm{g} / \mathrm{g}$.
Patients (24, 25, 20 and 2 KD) had NYHA class I, II, III, IV, respectively. All controls had NYHA class I. A large number of KD patients showed abnormal ECG, the most common disorders were conduction disorder and cardiac load. All chronic KD patients showed cardiac dilation on echocardiography.

Unusual signs and symptoms of Se poisoning were observed in this population. Neurological signs were found in 18 out of 22 rural residents affected by severe selenosis: acroparesthesia and dysestesia, hyperreflexia, convulsions, motor weakness and hemiplegia, polyneuritis.

Inorganic Se seemed to increase mortality from some site-specific cancers (melanoma, multiple myeloma, lymphoid neoplasms as well as colorectal and kidney cancer) and neurodegenerative diseases like Parkinson's disease and ALS, while lower breast cancer mortality was found.

Se intake of children from two cities was adequate but the inclusion of Brazil nuts in Macapà diet resulted in excess Se dietary intake, although children from this city did not present symptoms of selenosis (i.e. changes to and loss of nails and hair, skin lesions, unusual garlic odor on the breath, nervous system defects).

Chronic exposure to high Se through the soil-plant water continuum could place the human population at risk of developing impaired organ function. 
Studies in populations with 'intermediate' selenium status. Several studies have investigated the effects on human health of even limited changes in exposure to environmental selenium, which occurs through different environmental sources (primarily diet, but also air pollution, occupational environment, smoking and drinking water), in populations characterized by exposure levels not considered a priori to be unusually 'low' or 'high' (14). These studies, generally carried out in Western populations, have investigated a broad number of health outcomes, but in the majority of cases they focused on cancer risk $(14,15)$. However, most of these studies had an observational design, thus suffering from the potential severe bias due to unmeasured confounding and exposure misclassification even in prospective cohort studies, in addition to the other biases typically effecting studies with case-control, cross-sectional and clearly ecologic design $(1,14,29)$. In addition, their results have frequently been conflicting even for the same cancer type, as shown for instance for liver cancer $(30,31)$, lung cancer (32-34) or breast cancer (35-38), though in most cases they supported the occurrence of an inverse relation between selenium status and cancer risk (1). Luckily and rather unexpectedly for a nutrient with also was known to exert a powerful toxicity, the nutritional interest in this metalloid as well as the extremely 'attractive' preliminary results of the first selenium trial carried out in Western countries, the Nutrition Prevention of Cancer (NPC) trial (39), a large number of randomized controlled trials have been conducted during the last two decades. The aim of these studies has been to investigate the effects on cancer risk of an increased intake of this element $(1,40)$.

In Table II, we report the main features and results of these human studies with experimental design, including an assessment of the possible or established bias of this study based on our evaluation and the criteria developed within the Cochrane Collaboration network (41). In this overview, 'old' selenium trials carried out in China are also reported, but their scientific interest is very limited, if any, due to their very high risk of bias, as reported in detail in a previous assessment (1). Fortunately, these RCTs have generated a clear and consistent pattern of evidence about the effect of selenium on cancer risk, though partially unexpected given the underlying hypothesis which generated the trials, i.e. a beneficial effect of selenium on cancer risk (15). This is even more particularly with reference to the cancer type originally suggested by NPC to be most strongly associated with a beneficial effect of selenium, prostate cancer (39). In addition, these studies contributed in elucidating the relation between selenium and cardiovascular risk, another major issue of interest (42). Moreover, these trials have been fundamental in our understanding of the adverse effects of environmental selenium, rather unexpectedly since they encompassed supplementation of selenium doses considered a priori to be entirely safe $(1,15)$. Therefore, and differently from other elements of comparable toxicity and of less nutritional interest, the risk assessment of environmental selenium has benefitted from the implementation of experimental studies originally designed for a setting of potential selenium deficiency, but later found to be able to show and identify the early signs and symptoms related to the toxicity of this element.
Overall, all the recent trials have consistently shown that selenium does not modify risk of overall cancer, prostate cancer and other specific cancers $(2,3,23,43-45)$, while it may even increase risk of cancers such as advanced $(46,47)$ or overall prostate cancer $(48)$, non-melanoma skin cancer $(49,50)$ and possibly breast cancer in high-risk women (51). These results strongly and unexpectedly differ from the results reported in the earliest trial, the NPC $(49,52)$, which however was small and more importantly was later found to be affected by a detection bias (53). As previously mentioned, these trials have also been of fundamental (and unforeseen) importance in identifying the early signs, symptoms and diseases associated with chronic or subchronic selenium toxicity. In fact, they have shown that already at amount of selenium exposure (baseline dietary intake plus supplementation) of around 250-300 $\mu \mathrm{g} /$ day there is an increased risk of type-2 diabetes. Such excess diabetes risk linked to selenium overexposure was first discovered in trial carried out in a population with a 'low' baseline selenium status $(15,22)$ and later confirmed in large trials $(3,23)$. Finally, the largest of the selenium RCTs, SELECT (23), whose overall selenium intake in the supplemented group averaged $300 \mu \mathrm{g} /$ day (15), has shown that such amount of exposure induces 'minor' adverse effects such as dermatitis and alopecia [a long-recognized sign of selenium toxicity (12)]. These effects indicate that the selenium lowerobserved-adverse-effect-level (LOAEL) is much lower than previously considered by regulatory agencies $(5,54)$, which could base their assessment on the scarce data yielded by a few old Chinese environmental studies (55), calling for an update of the risk assessment of this element $(5,15,56,57)$.

\section{Adequacy of environmental standards}

An issue therefore arises about the adequacy of current standards for environmental risk assessment of selenium in the human, for both abnormally low and high exposures. These standards have been defined by a number of agencies since 2000 to 2014, and as summarized in Fig. 2 they encompass minimal recommended values ranging from 30 to $70 \mu \mathrm{g} / \mathrm{day}$, and upper doses ranging from 300 to $400 \mu \mathrm{g} /$ day (in adults) for overall selenium exposure $(4,16,58-61)$. On the contrary, specific guidelines for single selenium species have not been unfortunately set, despite the clear evidence that the various chemical forms of selenium have different biological properties, i.e. nutritional and toxicological activities $(7,9,10,62)$.

So far, the adequacy of the selenium standards has been mainly based on biochemical endpoints (for the lowest recommended intake) and on the occurrence of adverse health outcomes (for the upper level), as identified in old studies carried out in seleniferous areas from China. However, the newly available data from the clinical trials indicate the need of a substantial reassessment of the dose of selenium toxicity, though they unfortunately do not allow to clearly identify a NOAEL and probably also a reliable LOAEL, since only one supplemental dose (200 $\mu \mathrm{g} /$ selenium/day) have been used in these trials and dose-response data are lacking. However, using an uncertainty factor as little as 3,i.e. lower that the uncertainty factors usually adopted in risk assessment (10 or more) also in light of the peculiar nature of this element and its nutritional relevance, selenium intake should not exceed $90 \mu \mathrm{g} /$ day taking 


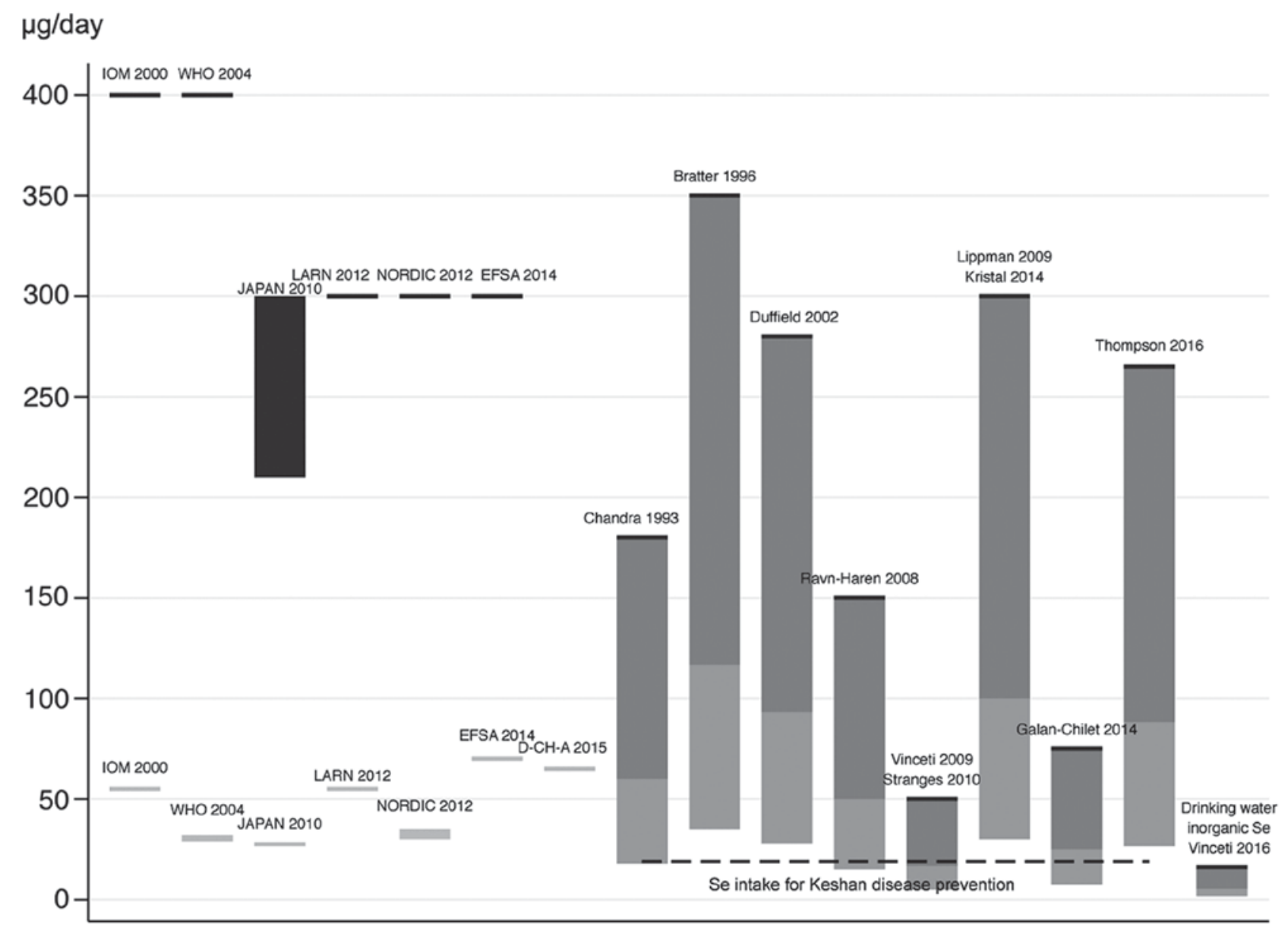

Figure 2. Comparison between environmental and dietary upper and lower standards for selenium (left) and the thresholds of adverse health effects of selenium (right) using an uncertain factor of 3 (dark grey) and of 10 (light gray). Data refer to daily overall selenium dietary intake.

into account the signs of toxicity yielded by the NPC trial (an excess diabetes and skin cancer risk) and by the SELECT trial (an excess incidence of diabetes, advanced prostate cancer, dermatitis and alopecia) (1), as shown in Fig. 2. However, this estimate may be still inadequate to protect human health from chronic selenium toxicity, and in addition it appears to apply only to organic selenium, and to selenomethionine in particular [whose toxicity has bene recently much better elucidated (63-65)].

For inorganic selenium, typically selenate such as those found in underground and drinking waters, the epidemiologic evidence points to a much higher toxicity compared with organic selenium and exactly as expected on the basis of experimental studies (10), therefore suggesting much lower acceptable environmental standards (57), tentatively $1 \mu \mathrm{g} / 1$ for drinking water (5). New standards should also be considered for occupational exposure to selenium, given the limited data available and the potential for toxicity of this source of exposure $(12,13,66,67)$. Finally, air selenium might represent a so far overlooked risk factor for chronic diseases, taking into account that its outdoor air concentrations have been positively associated with cardiovascular mortality (68) and with childhood leukemia risk (69), though more evidence is clearly required to confirm such possible associations mainly due to the inherent risk of unmeasured confounding in these observational studies.
The lowest acceptable amount of selenium exposure is instead much more controversial and uncertain. Two approaches have been used to define such lowest safe level of exposure: the proteomic change induced by the trace element, and the avoidance of adverse health effects. Concerning the latter point (health issues), still limited and inconclusive evidence is available on the large number of diseases tentatively ascribed to a deficiency of environmental selenium $(4,70)$, such as the chronic degenerative osteoarthropathy with unclear etiology named 'Kashin-Beck' disease $(71,72)$ and an increased susceptibility to viral infections $(73,74)$.

In addition, the hypothesis of an effect of 'low' environmental selenium exposure in increasing cancer risk may now be ruled out, thanks to the consistent evidence yielded by the recent large and well-conducted randomized trials, which ruled out any preventive effect of selenium on cancer risk. On the converse, evidence exists on the involvement of selenium deficiency on the etiology of a rare but severe cardiomyopathy named Keshan disease and endemic in some Chinese areas $(17,18,20,75-77)$, and this observation has played a key role in the identification of the minimal amount of selenium which appears to be required in humans $(4,78)$. Such involvement has been suggested mainly on the basis of observational evidence, i.e. a lower selenium status in the populations more affected by this disease, and following the beneficial effects of a selenium supplementation trial on disease incidence. 
Table II. Overview and main details of the randomized controlled trials with selenium supplementation in cancer prevention.

\begin{tabular}{|c|c|c|c|c|c|c|}
\hline Trial & Region & Population $^{\mathrm{a}}$ & $\begin{array}{l}\text { Type of Se } \\
\text { supplement }\end{array}$ & $\begin{array}{l}\text { Median } \\
\text { follow-up } \\
\text { or duration }\end{array}$ & $\begin{array}{c}\text { Risk of } \\
\text { bias }\end{array}$ & Main results \\
\hline $\begin{array}{l}\text { PLC prevention in } \\
\text { general population } \\
(115,116)\end{array}$ & China & $\begin{array}{l}130471(20847 / 109624) \\
\text { Subjects at high } \\
\text { risk to PLC }\end{array}$ & $\begin{array}{l}\text { Se-salt tablet with } \\
15 \mathrm{ppm} \text { anhydrous } \\
\text { sodium selenite }\end{array}$ & Up to 5 years & $\begin{array}{l}\text { Very } \\
\text { high } \\
\text { risk }\end{array}$ & $\begin{array}{l}\text { Reduction of PLC incidence } \\
\text { in township treated respect } \\
\text { other four placebo treated }\end{array}$ \\
\hline $\begin{array}{l}\text { PLC prevention in } \\
\text { HBsAg carriers } \\
(116,117)\end{array}$ & China & $\begin{array}{l}226(113 / 113) \text { Subjects } \\
\text { HBsAg carriers } \\
\text { in area with high } \\
\text { PLC incidence }\end{array}$ & $\begin{array}{l}200 \mu \mathrm{g} / \text { day } \\
\text { selenized yeast }\end{array}$ & Up to 4 years & $\begin{array}{l}\text { Very } \\
\text { high } \\
\text { risk }\end{array}$ & $\begin{array}{l}0 \text { and } 5 \text { PLC cases in } \\
\text { Se supplement } \\
\text { and placebo arms, } \\
\text { respectively }\end{array}$ \\
\hline $\begin{array}{l}\text { PLC prevention in } \\
\text { members of } \\
\text { families with high } \\
\text { PLC incidence } \\
\text { (116) }\end{array}$ & China & $\begin{array}{l}2474(1444 / 1030) \\
\text { Members of families } \\
\text { with high incidence } \\
\text { of PLC }\end{array}$ & $\begin{array}{l}200 \mu \mathrm{g} / \text { day } \\
\text { selenized yeast }\end{array}$ & Up to 2 years & $\begin{array}{l}\text { Very } \\
\text { high } \\
\text { risk }\end{array}$ & $\begin{array}{l}\text { PLC: } R^{b} 0.55 \\
(95 \% \text { CI } 0.22-1.35)\end{array}$ \\
\hline $\begin{array}{l}\text { PLC prevention in } \\
\text { members of } \\
\text { families with high } \\
\text { PLC incidence } \\
\text { (117) }\end{array}$ & China & $\begin{array}{l}3849(2364 / 1485) \\
\text { Members of families } \\
\text { with high incidence } \\
\text { of PLC }\end{array}$ & $\begin{array}{l}200 \mu \mathrm{g} / \text { day } \\
\text { selenized yeast }\end{array}$ & Up to 2 years & $\begin{array}{l}\text { Very } \\
\text { high } \\
\text { risk }\end{array}$ & $\begin{array}{l}\text { PLC: } \text { RR }^{b} 0.39 \\
(95 \% \text { CI } 0.10-1.36)\end{array}$ \\
\hline $\begin{array}{l}\text { PLC prevention in } \\
\text { HBsAg carriers } \\
(118)\end{array}$ & China & $\begin{array}{l}2065(1112 / 953) \\
\text { Subjects HBsAg } \\
\text { carriers in area with } \\
\text { high PLC incidence }\end{array}$ & $\begin{array}{l}0.5 \mathrm{mg} \text { sodium } \\
\text { selenite tablet }\end{array}$ & Up to 3 years & $\begin{array}{l}\text { Very } \\
\text { high } \\
\text { risk }\end{array}$ & $\begin{array}{l}\text { PLC: } R^{b} 0.51 \\
(95 \% \text { CI } 0.32-0.80)\end{array}$ \\
\hline $\begin{array}{l}\text { NPC - Nutritional } \\
\text { Prevention of } \\
\text { Cancer study } \\
(49,52)\end{array}$ & USA & $\begin{array}{l}1250(621 / 629) \text { in } 2002 \\
\text { Subjects with history } \\
\text { of basal or squamous } \\
\text { cell skin cancer }\end{array}$ & $\begin{array}{l}200 \mu \mathrm{g} / \text { day high- } \\
\text { high-selenium } \\
\text { yeast }\end{array}$ & $\begin{array}{l}\text { Mean } 7.9 \text { years } \\
\text { up to } 13 \text { years } \\
\text { (end of blinded } \\
\text { period) }\end{array}$ & $\begin{array}{l}\text { High } \\
\text { risk }\end{array}$ & $\begin{array}{l}\text { Any cancer: HR 0.75 } \\
\text { (95\% CI 0.58-0.97) } \\
\text { Bladder cancer: HR } 1.28 \\
\text { (95\% CI 0.50-3.25) } \\
\text { Breast cancer: HR } 1.89 \\
\text { (95\% CI 0.69-5.14) } \\
\text { Colorectal cancer: HR } 0.46 \\
\text { (95\% CI 0.21-1.02) } \\
\text { Lung cancer: HR 0.74 } \\
\text { (95\% CI 0.44-1.24) } \\
\text { Melanoma: HR 1.18 } \\
\text { (95\% CI 0.49-2.85) } \\
\text { NMSC: HR 1.17 } \\
\text { (95\% CI 1.02-1.34) } \\
\text { Prostate cancer: HR } 0.48 \\
\text { (95\% CI 0.28-0.80) }\end{array}$ \\
\hline $\begin{array}{l}\text { Organ transplant } \\
\text { recipients }(50)\end{array}$ & France & $\begin{array}{l}184(91 / 93) \\
\text { Organ graft (liver, } \\
\text { kidney or heart) } \\
\text { recipients aged 18-65 }\end{array}$ & $\begin{array}{l}200 \mu \mathrm{g} / \text { day } \\
\text { selenium enriched } \\
\text { yeast }\end{array}$ & $\begin{array}{l}\text { Up to } 5 \text { years } \\
\text { ( } 3 \text { of treatment } \\
\text { and } 2 \text { only of } \\
\text { follow-up) }\end{array}$ & $\begin{array}{l}\text { High } \\
\text { risk }\end{array}$ & $\begin{array}{l}\text { Skin keratoses: RR }{ }^{\mathrm{b}} 1.09 \\
(95 \% \text { CI } 0.65-1.84) \\
\text { Skin cancers: RR } 3.07 \\
(95 \% \text { CI } 0.55-31.06)\end{array}$ \\
\hline $\begin{array}{l}\text { SELECT - } \\
\text { Selenium and } \\
\text { Vitamin E Cancer } \\
\text { Prevention Trial } \\
(2,23,119,120)\end{array}$ & $\begin{array}{l}\text { USA, } \\
\text { Canada } \\
\text { and } \\
\text { Puerto } \\
\text { Rico }\end{array}$ & $\begin{array}{l}17448(8752 / 8696) \\
\text { Healthy men } \\
\geq 50 \text { years, } \\
\text { not suspicious } \\
\text { for cancer }\end{array}$ & $\begin{array}{l}200 \mu \mathrm{g} / \mathrm{day} \\
\text { selenized yeast/ } \\
\text { 1-selenomethionine }\end{array}$ & $\begin{array}{l}\text { Median } \\
5.46 \text { years }\end{array}$ & $\begin{array}{l}\text { Low } \\
\text { risk }\end{array}$ & $\begin{array}{l}\text { Any cancer: HR } 1.01 \\
(99 \% \text { CI 0.89-1.15) } \\
\text { Bladder cancer: HR } 1.13 \\
\text { (99\% CI 0.78-1.63) } \\
\text { Colorectal cancer: HR } 1.05\end{array}$ \\
\hline
\end{tabular}


Table II. Continued.

\begin{tabular}{|c|c|c|c|c|c|c|}
\hline Trial & Region & Population $^{\mathrm{a}}$ & $\begin{array}{l}\text { Type of Se } \\
\text { supplement }\end{array}$ & $\begin{array}{l}\text { Median } \\
\text { follow-up } \\
\text { or duration }\end{array}$ & $\begin{array}{c}\text { Risk of } \\
\text { bias }\end{array}$ & Main results \\
\hline & & $\begin{array}{l}\text { at digital rectal } \\
\text { examination }\end{array}$ & & & & $\begin{array}{l}\text { (99\% CI 0.66-1.67) } \\
\text { Lung cancer: HR 1.12 } \\
\text { (99\% CI 0.73-1.72) } \\
\text { Prostate cancer: HR } 1.04 \\
\text { (99\% CI 0.87-1.24) } \\
\text { Cardiovascular events: } \\
\text { HR } 1.07 \text { (99\% CI 0.94-1.22) }\end{array}$ \\
\hline $\begin{array}{l}\text { BRCA1 carriers } \\
(51)\end{array}$ & Poland & $\begin{array}{l}1,135 \text { Women } \\
\text { BRCA1 carriers }\end{array}$ & $\begin{array}{l}250 \mu \mathrm{g} / \mathrm{day} \\
\text { inorganic } \\
\text { selenite }\end{array}$ & $\begin{array}{l}\text { Median } \\
2.92 \text { years }\end{array}$ & $\begin{array}{l}\text { Not } \\
\text { evaluable }\end{array}$ & $\begin{array}{l}\text { Any cancer: HR } 1.4 \\
(95 \% \text { CI 0.9-2.0) } \\
\text { Breast cancer: HR } 1.3 \\
(95 \% \text { CI } 0.7-2.5)\end{array}$ \\
\hline $\begin{array}{l}\text { SWOG (Southwest } \\
\text { Oncology Group) } \\
\text { Trial S9917 (121) }\end{array}$ & USA & $\begin{array}{l}423(212 / 211) \text { Men } \\
\text { aged } \geq 40 \text { years with } \\
\text { biopsy-confirmed } \\
\text { diagnosis of HGPIN } \\
\text { but cancer free }\end{array}$ & $\begin{array}{l}200 \mu \mathrm{g} / \mathrm{day} \\
\text { selenium }\end{array}$ & $\begin{array}{l}\text { Up to } \\
3 \text { years }\end{array}$ & $\begin{array}{l}\text { Low } \\
\text { risk }\end{array}$ & $\begin{array}{l}\text { Prostate cancer: RR } 0.97 \\
(95 \% \text { CI } 0.68-1.39)\end{array}$ \\
\hline $\begin{array}{l}\text { NBT - Negative } \\
\text { Biopsy Trial (44) }\end{array}$ & $\begin{array}{l}\text { USA } \\
\text { and } \\
\text { New } \\
\text { Zealand }\end{array}$ & $\begin{array}{l}699(467 / 232) \\
\text { Men aged <80 years } \\
\text { at high risk for } \\
\text { prostate cancer, } \\
\text { negative for } \\
\text { cancer or HGPIN }\end{array}$ & $\begin{array}{l}234 \text { with } \\
200 \mu \mathrm{g} / \text { day } \\
\text { and } 233 \text { with } \\
400 \mu \mathrm{g} / \text { day } \\
\text { selenized yeast }\end{array}$ & $\begin{array}{l}\text { Median } \\
3 \text { years } \\
\text { Up to } \\
5 \text { years }\end{array}$ & $\begin{array}{l}\text { Low } \\
\text { risk }\end{array}$ & $\begin{array}{l}\text { Any cancer: RR } \mathrm{R}^{\mathrm{b}} 0.98 \\
(95 \% \text { CI } 0.64-1.52) \\
\text { Colon cancer: } \mathrm{RR}^{\mathrm{b}} 0.99 \\
(95 \% \text { CI } 0.05-58.62) \\
\text { Melanoma: } \mathrm{RR}^{\mathrm{b}} 1.24 \\
(95 \% \text { CI } 0.20-13.04) \\
\text { NMSC: RR } 0.57 \\
(95 \% \text { CI } 0.35-0.95) \\
\text { Prostate cancer: } \mathrm{RR}^{\mathrm{b}} 0.98 \\
(95 \% \text { CI } 0.64-1.52)\end{array}$ \\
\hline $\begin{array}{l}\text { Eastern } \\
\text { Cooperative } \\
\text { Oncology Group } \\
\text { (ECOG) Trial } 5597 \\
(45)\end{array}$ & USA & $\begin{array}{l}1,561(1040 / 521) \\
\text { Adult subjects with } \\
\text { resected Stage I } \\
\text { Non-small cell } \\
\text { lung cancer }\end{array}$ & $\begin{array}{l}200 \mu \mathrm{g} / \mathrm{day} \\
\text { selenized yeast }\end{array}$ & $\begin{array}{l}\text { Up to } \\
4 \text { years }\end{array}$ & $\begin{array}{l}\text { Low } \\
\text { risk }\end{array}$ & $\begin{array}{l}\text { Secondary primary tumors: } \\
\text { Any cancer: RR } 1.02 \\
\text { (95\% CI 0.78-1.34) } \\
\text { Bladder cancer: RR } 0.75 \\
\text { (95\% CI 0.24-2.67) } \\
\text { Colonrectal cancer: RR } 0.50 \\
\text { (95\% CI 0.09-2.69) } \\
\text { Lung cancer: } R^{\mathrm{b}} 1.26 \\
\text { (95\% CI 0.77-2.15) } \\
\text { Melanoma: } \mathrm{RR}^{\mathrm{b}} 1.25 \\
\text { (95\% CI 0.21-13.15) } \\
\text { NMSC: RR } 0.70 \\
(95 \% \text { CI } 0.36-1.35) \\
\text { Prostate cancer: RRb } 0.89 \\
(95 \% \text { CI } 0.37-2.29)\end{array}$ \\
\hline $\begin{array}{l}\text { Selenium and } \\
\text { Celecoxib } \\
\text { (Sel/Cel) } \\
\text { Trial (3) }\end{array}$ & USA & $\begin{array}{l}1,374(685 / 689) \\
\text { subjects aged } \\
40-80 \text { years following } \\
\text { colonoscopic removal } \\
\text { of colorectal adenomas }\end{array}$ & $\begin{array}{l}200 \mu \mathrm{g} / \mathrm{day} \\
\text { selenized yeast }\end{array}$ & $\begin{array}{l}\text { Median } \\
2.96 \text { years }\end{array}$ & $\begin{array}{l}\text { Low } \\
\text { risk }\end{array}$ & $\begin{array}{l}\text { Any adenoma: RR } 1.03 \\
\text { (95\% CI 0.91-1-16) } \\
\text { Advanced adenoma: } \\
\text { RR } 1.02 \text { (95\% CI 0.74-1.43) } \\
\text { Multiple ( } \geq 3 \text { ) adenoma: } \\
\text { RR } 1.47 \text { (95\% CI 1.08-2.02) } \\
\text { Squamous cell ca: RR } 1.34 \\
\text { (95\% CI } 0.76-2.37)\end{array}$ \\
\hline
\end{tabular}

HBsAg, hepatitis B virus surface antigen S; HGPIN, high-grade prostatic intraepithelial neoplasia; PLC, primary liver cancer; NMSC, non-melanoma

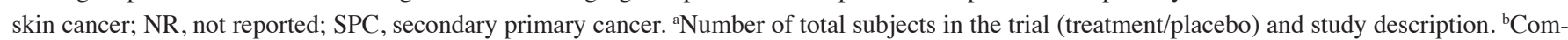
puted using the 'iri' routine of STATA 14.1 (Stata Corp., College Station, TX, USA). 
However, some epidemiologic features of the disease have since the discovery of the disease suggested alternative etiologic hypotheses (79), particularly a cardiotropic infectious agent such as a Coxsackie virus, selenium deficiency possibly being a cofactor in disease etiology or simply an innocent bystander $(19,20,54,77)$. Under this perspective, the beneficial effect of selenium supplementation in a Chinese trial might be interpreted as an indication of antiviral effects of the selenium compound used (inorganic tetravalent selenium, i.e. selenite), as suggested by laboratory studies $(40,80)$. In any case, while still investigating the cause of Keshan disease and the possible involvement of selenium status, it is prudent to avoid a too low intake of selenium under the hypothesis of a role in Keshan disease etiology, and therefore average population intake must be higher than that shown to be required to avoid disease incidence, i.e. $13.3 \mu \mathrm{g} / \mathrm{day}$ in females and 19.1 in males (16). Finally, recent evidence has suggested adverse health effects of mutations affecting Sec insertion sequence-binding protein 2 or the selenoprotein N1 gene (81-83), though such abnormalities might not be strictly related to a 'selenium deficiency' neither were they corrected by its supplementation (84), thus being of limited interest in the setting of minimal dietary selenium requirements.

Alternatively, to the use of health endpoints, and considerably more frequently, the amount of the selenium needed to induce the maximization of selenoprotein synthesis (particularly glutathione-peroxidase and plasma selenoprotein $\mathrm{P}$ ) has been proposed to set the minimal requirement of selenium in the human. This approach has been based on the assumption that achievement of this biochemical endpoint, i.e. upregulation (frequently defined as 'optimization') of selenoprotein synthesis indicates the achievement of an adequate supply of this trace element to the human $(40,85)$. This would point to adequate dietary intake (considering this as only source of selenium exposure) of amount in the order of $70 \mu \mathrm{g} /$ day (85), thus reaching or even exceeding the upper limit definable on the basis of the SELECT trial results using an uncertainty factor of 3 and clearly even more, of course, when using an uncertainty factor of 10 (Fig. 2). In addition, this 'biochemical' approach does not take into account that selenoprotein maximization which follows selenium species administration may derive not just from the 'correction' of a nutritional deficiency of the trace element, but as a compensatory response of these proteins (all characterized by antioxidant properties) to the pro-oxidant activity of selenium species $(40,54,86-94)$.

There is also little evidence showing that selenoprotein activity, and particularly its maximization, are beneficial to human health, and therefore (as more generally levels for antioxidant enzymes) this should not be regarded as an objective unless more evidence in humans are provided $(40,54)$. This approach is further strengthened when taking into account that these enzymes are physiologically induced and inducible by oxidative stress (for selenoproteins, even in the absence of any change in selenium supply) $(40,54)$, as long recognized since the discovery of the selenium-containing antioxidant enzyme glutathione-peroxidase (95-97). Overall, it seems therefore prudent to avoid a maximal expression of selenoproteins $(54,98)$, setting as standard a lower amount of their activity, such as proposed by WHO when suggesting a 'nutritionally adequate' target ('recommended nutrient intake') the achievement of two thirds of the maximal selenoprotein activity, corresponding to a daily selenium intake of 25-34 $\mu \mathrm{g}$ in adults (Fig. 2). However, more research is clearly required to set reliable lower and upper safe selenium levels, though the current standards need to be quickly updated with reference to the upper levels taking into account the above-mentioned recent results of the epidemiologic studies, i.e. the high-quality RCTs and the environmental studies, and also considering the opportunity to set species-specific standards for this element.

\section{References}

1. Vinceti M, Dennert G, Crespi CM, Zwahlen M, Brinkman M, Zeegers MP, Horneber M, D'Amico R and Del Giovane C: Selenium for preventing cancer. Cochrane Database Syst Rev 3: CD005195, 2014.

2. Lance P, Alberts DS, Thompson PA, Fales L, Wang F, San Jose J, Jacobs ET, Goodman PJ, Darke AK, Yee M, et al: Colorectal adenomas in participants of the SELECT randomized trial of selenium and vitamin $\mathrm{E}$ for prostate cancer prevention. Cancer Prev Res (Phila) 10: 45-54, 2017.

3. Thompson PA, Ashbeck EL, Roe DJ, Fales L, Buckmeier J, Wang F, Bhattacharyya A, Hsu CH, Chow HH, Ahnen DJ, et al: Selenium supplementation for prevention of colorectal adenomas and risk of associated type 2 diabetes. J Natl Cancer Inst 108: pii: djw152, 2016.

4. Institute of Medicine Food and Nutrition Board: Dietary references intakes for vitamin $\mathrm{C}$, vitamin $\mathrm{E}$, selenium, and carotenoids. National Academy Press, Washington, DC, 2000.

5. Vinceti M, Crespi CM, Bonvicini F, Malagoli C, Ferrante M, Marmiroli S and Stranges S: The need for a reassessment of the safe upper limit of selenium in drinking water. Sci Total Environ 443: 633-642, 2013.

6. Rothman KJ, Greenland S and Lash TL: Modern Epidemiology. Lippincott Williams \& Wilkins, Philadelphia, 2012.

7. Michalke B, Halbach S and Nischwitz V: JEM spotlight: Metal speciation related to neurotoxicity in humans. J Environ Monit 11: 939-954, 2009.

8. Gammelgaard B, Jackson MI and Gabel-Jensen C: Surveying selenium speciation from soil to cell--forms and transformations. Anal Bioanal Chem 399: 1743-1763, 2011.

9. Weekley CM and Harris HH: Which form is that? The importance of selenium speciation and metabolism in the prevention and treatment of disease. Chem Soc Rev 42: 8870-8894, 2013.

10. Vinceti M, Solovyev N, Mandrioli J, Crespi CM, Bonvicini F, Arcolin E, Georgoulopoulou E and Michalke B: Cerebrospinal fluid of newly diagnosed amyotrophic lateral sclerosis patients exhibits abnormal levels of selenium species including elevated selenite. Neurotoxicology 38: 25-32, 2013.

11. Vinceti M, Grill P, Malagoli C, Filippini T, Storani S, Malavolti M and Michalke B: Selenium speciation in human serum and its implications for epidemiologic research: A cross-sectional study. J Trace Elem Med Biol 31: 1-10, 2015.

12. Vinceti M, Wei ET, Malagoli C, Bergomi M and Vivoli G: Adverse health effects of selenium in humans. Rev Environ Health 16: 233-251, 2001.

13. Vinceti M, Mandrioli J, Borella P, Michalke B, Tsatsakis A and Finkelstein Y: Selenium neurotoxicity in humans: Bridging laboratory and epidemiologic studies. Toxicol Lett 230: 295-303, 2014.

14. Vinceti M, Crespi CM, Malagoli C, Del Giovane C and Krogh V: Friend or foe? The current epidemiologic evidence on selenium and human cancer risk. J Environ Sci Health C Environ Carcinog Ecotoxicol Rev 31: 305-341, 2013.

15. Vinceti M, Burlingame B, Fillippini T, Naska A, Bargellini A and Borella P: The epidemiology of selenium and human health. In: Selenium: Its Molecular Biology and Role in Human Health. Hatfield D, Schweizer U and Gladyshev VN (eds). 4th edition. Springer Science Business Media, New York, pp365-376, 2016.

16. Joint FAO/WHO Expert Consultation on Human Vitamin and Mineral Requirements: Vitamin and mineral requirements in human nutrition. 2nd edition. World Health Organization and Food and Agriculture Organization of the United Nations, Geneva, 2004. 
17. Keshan Disease Research Group of the Chinese Academy of Medical Sciences: Epidemiologic studies on the etiologic relationship of selenium and Keshan disease. Chin Med J (Engl) 92: 477-482, 1979

18. Keshan Disease Research Group of the Chinese Academy of Medical Sciences: Observations on effect of sodium selenite in prevention of Keshan disease. Chin Med J (Engl) 92: 471-476, 1979.

19. Wang T and Li Q: Interpretation of selenium deficiency and Keshan disease with causal inference of modern epidemiology. In: The 5th International Selenium Seminar. Organizing Committee of the International Selenium Seminar, Moscow, pp34-35, 2015.

20. Lei C, Niu X, Ma X and Wei J: Is selenium deficiency really the cause of Keshan disease? Environ Geochem Health 33: 183-188, 2011.

21. Winther KH, Bonnema SJ, Cold F, Debrabant B, Nybo M, Cold S and Hegedüs L: Does selenium supplementation affect thyroid function? Results from a randomized, controlled, double-blinded trial in a Danish population. Eur J Endocrinol 172: 657-667, 2015.

22. Stranges S, Marshall JR, Natarajan R, Donahue RP, Trevisan M, Combs GF, Cappuccio FP, Ceriello A and Reid ME: Effects of long-term selenium supplementation on the incidence of type 2 diabetes: A randomized trial. Ann Intern Med 147: 217-223, 2007.

23. Lippman SM, Klein EA, Goodman PJ, Lucia MS, Thompson IM, Ford LG, Parnes HL, Minasian LM, Gaziano JM, Hartline JA, et al: Effect of selenium and vitamin $\mathrm{E}$ on risk of prostate cancer and other cancers: The Selenium and Vitamin E Cancer Prevention Trial (SELECT). JAMA 301: 39-51, 2009.

24. Vinceti M, Rovesti S, Gabrielli C, Marchesi C, Bergomi M, Martini $\mathrm{M}$ and Vivoli G: Cancer mortality in a residential cohort exposed to environmental selenium through drinking water. J Clin Epidemiol 48: 1091-1097, 1995.

25. Vinceti M, Rothman KJ, Bergomi M, Borciani N, Serra L and Vivoli G: Excess melanoma incidence in a cohort exposed to high levels of environmental selenium. Cancer Epidemiol Biomarkers Prev 7: 853-856, 1998

26. Vinceti M, Ballotari P, Steinmaus C, Malagoli C, Luberto F, Malavolti M and Giorgi Rossi P: Long-term mortality patterns in a residential cohort exposed to inorganic selenium in drinking water. Environ Res 150: 348-356, 2016.

27. Saint-Amour D, Roy MS, Bastien C, Ayotte P, Dewailly E, Després C, Gingras S and Muckle G: Alterations of visual evoked potentials in preschool Inuit children exposed to methylmercury and polychlorinated biphenyls from a marine diet. Neurotoxicology 27: 567-578, 2006.

28. Vinceti M, Bonvicini F, Rothman KJ, Vescovi L and Wang F: The relation between amyotrophic lateral sclerosis and inorganic selenium in drinking water: A population-based case-control study. Environ Health 9: 77, 2010.

29. Vinceti M and Rothman KJ: More results but no clear conclusion on selenium and cancer. Am J Clin Nutr 104: 245-246, 2016.

30. Hughes DJ, Duarte-Salles T, Hybsier S, Trichopoulou A, Stepien M, Aleksandrova K, Overvad K, Tjønneland A, Olsen A, Affret A, et al: Prediagnostic selenium status and hepatobiliary cancer risk in the European Prospective Investigation into Cancer and Nutrition cohort. Am J Clin Nutr 104: 406-414, 2016.

31. Ma X, Yang Y, Li HL, Zheng W, Gao J, Zhang W, Yang G, Shu XO and Xiang YB: Dietary trace element intake and liver cancer risk: Results from two population-based cohorts in China Int J Cancer 140: 1050-1059, 2017.

32. Knekt P, Marniemi J, Teppo L, Heliövaara M and Aromaa A Is low selenium status a risk factor for lung cancer? Am J Epidemiol 148: 975-982, 1998

33. van den Brandt PA, Goldbohm RA, van 't Veer P, Bode P, Dorant E, Hermus RJ and Sturmans F: A prospective cohort study on selenium status and the risk of lung cancer. Cancer Res 53: 4860-4865, 1993.

34. Suadicani P, Hein HO and Gyntelberg F: Serum selenium level and risk of lung cancer mortality: A 16-year follow-up of the Copenhagen Male Study. Eur Respir J 39: 1443-1448, 2012.

35. Menkes MS, Comstock GW, Vuilleumier JP, Helsing KJ, Rider AA and Brookmeyer R: Serum beta-carotene, vitamins A and $\mathrm{E}$, selenium, and the risk of lung cancer. N Engl J Med 315: 1250-1254, 1986.

36. van Noord PA, Maas MJ, van der Tweel I and Collette C: Selenium and the risk of postmenopausal breast cancer in the DOM cohort. Breast Cancer Res Treat 25: 11-19, 1993.
37. van den Brandt PA, Goldbohm RA, van't Veer P, Bode P, Dorant E, Hermus RJ and Sturmans F: Toenail selenium levels and the risk of breast cancer. Am J Epidemiol 140: 20-26, 1994.

38. Garland M, Morris JS, Stampfer MJ, Colditz GA, Spate VL, Baskett CK, Rosner B, Speizer FE, Willett WC and Hunter DJ: Prospective study of toenail selenium levels and cancer among women. J Natl Cancer Inst 87: 497-505, 1995.

39. Clark LC, Combs GFJ Jr, Turnbull BW, Slate EH, Chalker DK, Chow J, Davis LS, Glover RA, Graham GF, Gross EG, et al; Nutritional Prevention of Cancer Study Group: Effects of selenium supplementation for cancer prevention in patients with carcinoma of the skin. A randomized controlled trial. JAMA 276 1957-1963, 1996.

40. Jablonska E and Vinceti M: Selenium and Human Health: Witnessing a Copernican Revolution? J Environ Sci Health C Environ Carcinog Ecotoxicol Rev 33: 328-368, 2015.

41. Higgins JP: A revised tool to assess risk of bias in randomized trials (RoB 2.0). 2016.

42. Rees K, Hartley L, Day C, Flowers N, Clarke A and Stranges S: Selenium supplementation for the primary prevention of cardiovascular disease. Cochrane Database Syst Rev 1: CD009671, 2013.

43. Stratton MS, Reid ME, Schwartzberg G, Minter FE, Monroe BK, Alberts DS, Marshall JR and Ahmann FR: Selenium and prevention of prostate cancer in high-risk men: The Negative Biopsy Study. Anticancer Drugs 14: 589-594, 2003.

44. Algotar AM, Stratton MS, Ahmann FR, Ranger-Moore J, Nagle RB, Thompson PA, Slate E, Hsu CH, Dalkin BL, Sindhwani $\mathrm{P}$, et al: Phase 3 clinical trial investigating the effect of selenium supplementation in men at high-risk for prostate cancer. Prostate 73: 328-335, 2013.

45. Karp DD, Lee SJ, Keller SM, Wright GS, Aisner S, Belinsky SA, Johnson DH, Johnston MR, Goodman G, Clamon G, et al: Randomized, double-blind, placebo-controlled, phase III chemoprevention trial of selenium supplementation in patients with resected stage I non-small-cell lung cancer: ECOG 5597. J Clin Oncol 31: 4179-4187, 2013.

46. Kristal AR, Darke AK, Morris JS, Tangen CM, Goodman PJ, Thompson IM, Meyskens FL Jr, Goodman GE, Minasian LM, Parnes HL, et al: Baseline selenium status and effects of selenium and vitamin e supplementation on prostate cancer risk. J Natl Cancer Inst 106: djt456, 2014.

47. Albanes D, Till C, Klein EA, Goodman PJ, Mondul AM, Weinstein SJ, Taylor PR, Parnes HL, Gaziano JM, Song X, et al: Plasma tocopherols and risk of prostate cancer in the Selenium and Vitamin E Cancer Prevention Trial (SELECT). Cancer Prev Res (Phila) 7: 886-895, 2014.

48. Martinez EE, Darke AK, Tangen CM, Goodman PJ, Fowke JH, Klein EA and Abdulkadir SA: A functional variant in NKX3.1 associated with prostate cancer risk in the Selenium and Vitamin E Cancer Prevention Trial (SELECT). Cancer Prev Res (Phila) 7: 950-957, 2014.

49. Duffield-Lillico AJ, Slate EH, Reid ME, Turnbull BW, Wilkins PA, Combs GF Jr, Park HK, Gross EG, Graham GF, Stratton MS, et al; Nutritional Prevention of Cancer Study Group: Selenium supplementation and secondary prevention of nonmelanoma skin cancer in a randomized trial. J Natl Cancer Inst 95: 1477-1481, 2003.

50. Dréno B, Euvrard S, Frances C, Moyse D and Nandeuil A: Effect of selenium intake on the prevention of cutaneous epithelial lesions in organ transplant recipients. Eur J Dermatol 17: 140-145, 2007.

51. Lubinski J, Jaworska K, Durda K, Jakubowska A, Huzarski T, Byrski T, Stawicka M, Gronwald J, Górski B, Wasowicz W, et al: Selenium and the risk of cancer in BRCA1 carriers. Hered Cancer Clin Pract 9 (Suppl 2): A5, 2011.

52. Duffield-Lillico AJ, Reid ME, Turnbull BW, Combs GFJ Jr, Slate EH, Fischbach LA, Marshall JR and Clark LC: Baseline characteristics and the effect of selenium supplementation on cancer incidence in a randomized clinical trial: A summary report of the Nutritional Prevention of Cancer Trial. Cancer Epidemiol Biomarkers Prev 11: 630-639, 2002.

53. Duffield-Lillico AJ, Dalkin BL, Reid ME, Turnbull BW, Slate EH, Jacobs ET, Marshall JR and Clark LC; Nutritional Prevention of Cancer Study Group: Selenium supplementation, baseline plasma selenium status and incidence of prostate cancer: An analysis of the complete treatment period of the Nutritional Prevention of Cancer Trial. BJU Int 91: 608-612, 2003. 
54. Vinceti M, Maraldi T, Bergomi M and Malagoli C: Risk of chronic low-dose selenium overexposure in humans: Insights from epidemiology and biochemistry. Rev Environ Health 24: 231-248, 2009

55. Yang GQ, Wang SZ, Zhou RH and Sun SZ: Endemic selenium intoxication of humans in China. Am J Clin Nutr 37: 872-881, 1983.

56. Barron E, Migeot V, Rabouan S, Potin-Gautier M, Séby F, Hartemann P, Lévi Y and Legube B: The case for re-evaluating the upper limit value for selenium in drinking water in Europe. J Water Health 7: 630-641, 2009.

57. Frisbie SH, Mitchell EJ and Sarkar B: Urgent need to reevaluate the latest World Health Organization guidelines for toxic inorganic substances in drinking water. Environ Health 14: 63 , 2015.

58. Scientific Committee on Food: Opinion of the Scientific Committee on Food on the Tolerable Upper Intake Level of Selenium. European Commission, Brussels, 2000. https://ec. europa.eu/food/sites/food/files/safety/docs/sci-com_scf_out80g_ en.pdf.

59. Tsubota-Utsugi M, Imai E, Nakade M, Tsuboyama-Kasaoka N, Morita A and Tokudome S: Dietary Reference Intakes for Japanese - 2010. The summary report from the Scientific Committee of 'Dietary Reference intakes for Japanese'. National Institute of Health and Nutrition, Japan, 2012.

60. Nordic Nutrition Recommendations 2012. 5th edition. Nordic Council of Ministers, Copenhagen, 2014. doi: org/10.6027/ Nord2014-002.

61. Società Italiana di Nutrizione Umana: LARN - Livelli di assunzione di riferimento di nutrienti e energia per la popolazione italiana - IV revisione. SICS, Milan, 2014 (In Italian).

62. MarschallTA,Bornhorst J,KuehneltD and Schwerdtle T: Differing cytotoxicity and bioavailability of selenite, methylselenocysteine, selenomethionine, selenosugar 1 and trimethylselenonium ion and their underlying metabolic transformations in human cells. Mol Nutr Food Res 60: 2622-2632, 2016.

63. Lazard M, Dauplais M, Blanquet S and Plateau P: Transsulfuration pathway seleno-amino acids are mediators of selenomethionine toxicity in Saccharomyces cerevisiae. J Biol Chem 290: 10741-10750, 2015.

64. Raine JC, Lallemand L, Pettem CM and Janz DM: Effects of chronic dietary selenomethionine exposure on the visual system of adult and F1 generation zebrafish (Danio rerio). Bull Environ Contam Toxicol 97: 331-336, 2016.

65. Dolgova NV, Hackett MJ, MacDonald TC, Nehzati S, James AK, Krone PH, George GN and Pickering IJ: Distribution of selenium in zebrafish larvae after exposure to organic and inorganic selenium forms. Metallomics 8: 305-312, 2016.

66. Göen T, Schaller B, Jäger T, Bräu-Dümler Ch, Schaller KH and Drexler H: Biological monitoring of exposure and effects in workers employed in a selenium-processing plant. Int Arch Occup Environ Health 88: 623-630, 2015.

67. Jäger T, Drexler H and Göen T: Human metabolism and renal excretion of selenium compounds after oral ingestion of sodium selenate dependent on trimethylselenium ion (TMSe) status. Arch Toxicol 90: 149-158, 2016.

68. Ito K, Mathes R, Ross Z, Nádas A, Thurston G and Matte T: Fine particulate matter constituents associated with cardiovascular hospitalizations and mortality in New York City. Environ Health Perspect 119: 467-473, 2011.

69. Heck JE, Park AS, Qiu J, Cockburn M and Ritz B: Risk of leukemia in relation to exposure to ambient air toxics in pregnancy and early childhood. Int J Hyg Environ Health 217: 662-668, 2014

70. Burk RF Jr: Selenium deficiency in search of a disease Hepatology 8: 421-423, 1988.

71. Yu FF, Liu H and Guo X: Integrative multivariate logistic regression analysis of risk factors for Kashin-Beck disease. Biol Trace Elem Res 174: 274-279, 2016.

72. Yu FF, Zhang YX, Zhang LH, Li WR, Guo X and Lammi MJ: Identified molecular mechanism of interaction between environmental risk factors and differential expression genes in cartilage of Kashin-Beck disease. Medicine (Baltimore) 95: e5669, 2016.

73. Beck MA, Levander OA and Handy J: Selenium deficiency and viral infection. J Nutr 133 (Suppl 1): 1463S-1467S, 2003.

74. Sheridan PA, Zhong N, Carlson BA, Perella CM, Hatfield DL and Beck MA: Decreased selenoprotein expression alters the immune response during influenza virus infection in mice. J Nutr 137: 1466-1471, 2007.

75. Gu BQ: Pathology of Keshan disease. A comprehensive review. Chin Med J (Engl) 96: 251-261, 1983.
76. Levander OA and Beck MA: Interacting nutritional and infectious etiologies of Keshan disease. Insights from coxsackie virus B-induced myocarditis in mice deficient in selenium or vitamin E. Biol Trace Elem Res 56: 5-21, 1997.

77. Xu GL, Wang SC, Gu BQ, Yang YX, Song HB, Xue WL, Liang WS and Zhang PY: Further investigation on the role of selenium deficiency in the aetiology and pathogenesis of Keshan disease. Biomed Environ Sci 10: 316-326, 1997.

78. Chen J: An original discovery: Selenium deficiency and Keshan disease (an endemic heart disease). Asia Pac J Clin Nutr 21: 320-326, 2012

79. Guanqing H: On the etiology of Keshan disease: Two hypotheses Chin Med J (Engl) 92: 416-422, 1979.

80. Cermelli C, Vinceti M, Scaltriti E, Bazzani E, Beretti F, Vivoli G and Portolani M: Selenite inhibition of Coxsackie virus B5 replication: Implications on the etiology of Keshan disease. J Trace Elem Med Biol 16: 41-46, 2002.

81. Schoenmakers E, Agostini M, Mitchell C, Schoenmakers N, Papp L, Rajanayagam O, Padidela R, Ceron-Gutierrez L, Doffinger R, Prevosto C, et al: Mutations in the selenocysteine insertion sequence-binding protein 2 gene lead to a multisystem selenoprotein deficiency disorder in humans. J Clin Invest 120: 4220-4235, 2010

82. Scoto M, Cirak S, Mein R, Feng L, Manzur AY, Robb S, Childs AM, Quinlivan RM, Roper H, Jones DH, et al: SEPN1related myopathies: Clinical course in a large cohort of patients. Neurology 76: 2073-2078, 2011.

83. Ardissone A, Bragato C, Blasevich F, Maccagnano E, Salerno F, Gandioli C, Morandi L, Mora M and Moroni I: SEPN1-related myopathy in three patients: Novel mutations and diagnostic clues. Eur J Pediatr 175: 1113-1118, 2016.

84. Schomburg L, Dumitrescu AM, Liao XH, Bin-Abbas B, Hoeflich J, Köhrle J and Refetoff S: Selenium supplementation fails to correct the selenoprotein synthesis defect in subjects with SBP2 gene mutations. Thyroid 19: 277-281, 2009.

85. EFSA NDA Panel: Scientific opinion on dietary reference values for selenium. EFSA J 12: 3846, 2014.

86. Ge KY, Wang SQ, Bai J, Xue AN, Deng XJ, Su CQ and Wu SQ: The protective effect of selenium against viral myocarditis in mice. In: Selenium in biology and medicine. Part B. Combs GF, Spallholz JE, Levander OA and Oldfield JE (eds). Avi Book, Van Nostrand Reinhold Co., New York, pp761-768, 1987.

87. Spallholz JE: Free radical generation by selenium compounds and their prooxidant toxicity. Biomed Environ Sci 10: 260-270, 1997.

88. Stewart MS, Spallholz JE, Neldner KH and Pence BC: Selenium compounds have disparate abilities to impose oxidative stress and induce apoptosis. Free Radic Biol Med 26: 42-48, 1999.

89. Letavayová L, Vlasáková D, Spallholz JE, Brozmanová J and Chovanec M: Toxicity and mutagenicity of selenium compounds in Saccharomyces cerevisiae. Mutat Res 638: 1-10, 2008.

90. Misra S, Boylan M, Selvam A, Spallholz JE and Björnstedt M: Redox-active selenium compounds - from toxicity and cell death to cancer treatment. Nutrients 7: 3536-3556, 2015.

91. Lee KH and Jeong D: Bimodal actions of selenium essential for antioxidant and toxic pro-oxidant activities: The selenium paradox (Review). Mol Med Rep 5: 299-304, 2012.

92. Brozmanová J, Mániková D, Vlčková V and Chovanec M: Selenium: A double-edged sword for defense and offence in cancer. Arch Toxicol 84: 919-938, 2010.

93. Schiar VP, Dos Santos DB, Paixão MW, Nogueira CW, Rocha JB and Zeni G: Human erythrocyte hemolysis induced by selenium and tellurium compounds increased by GSH or glucose: A possible involvement of reactive oxygen species. Chem Biol Interact 177: 28-33, 2009

94. Guo CH, Hsia S, Hsiung DY and Chen PC: Supplementation with selenium yeast on the prooxidant-antioxidant activities and anti-tumor effects in breast tumor xenograft-bearing mice. J Nutr Biochem 26: 1568-1579, 2015.

95. Hafeman DG, Sunde RA and Hoekstra WG: Effect of dietary selenium on erythrocyte and liver glutathione peroxidase in the rat. J Nutr 104: 580-587, 1974.

96. Oh SH, Sunde RA, Pope AL and Hoekstra WG: Glutathione peroxidase response to selenium intake in lambs fed a Torula yeast-based, artificial milk. J Anim Sci 42: 977-983, 1976.

97. Kramer GF and Ames BN: Mechanisms of mutagenicity and toxicity of sodium selenite $\left(\mathrm{Na}_{2} \mathrm{SeO}_{3}\right)$ in Salmonella typhimurium. Mutat Res 201: 169-180, 1988.

98. Macallan DC and Sedgwick P: Selenium supplementation and selenoenzyme activity. Clin Sci (Lond) 99: 579-581, 2000. 
99. Tsongas TA and Ferguson SW: Selenium concentrations in human urine and drinking water. In: Proceedings of 'Trace Elements in Man and Animal-3'. Kirchgessner N (ed). Institute for Nursing Physiology Technical University Munchen, Freising, pp320-321, 1978.

100. Tsongas TA and Ferguson SW: Human health effects of selenium in a rural Colorado drinking water supply. In: Proceedings of 'Trace substances in environmental health-XI. A symposium' Hemphill DD (ed). University of Missouri, Columbia, pp30-35, 1977.

101. Valentine JL: Environmental occurrence of selenium in waters and related health significance. Biomed Environ Sci 10: 292-299, 1997.

102. Valentine JL, Kang HK, Dang PM and Schluchter M: Selenium concentrations and glutathione peroxidase activities in a population exposed to selenium via drinking water. J Toxicol Environ Health 6: 731-736, 1980.

103. Valentine JL, Faraji B and Kang HK: Human glutathione peroxidase activity in cases of high selenium exposures. Environ Res 45: 16-27, 1988.

104. Valentine JL, Reisbord LS, Kang HK and Schluchter M: Effects on human health of exposure to selenium in drinking water. In Proceedings of 'Selenium in Biology and Medicine - Part B'. Combs GF, Levander OA, Spallholz JE and Oldfield JE (eds). Van Nostrand Reihold Co., New York, pp675-687, 1987.

105.Longnecker MP, Taylor PR, Levander OA, Howe M, Veillon C, McAdam PA, Patterson KY, Holden JM, Stampfer MJ, Morris JS, et al: Selenium in diet, blood, and toenails in relation to human health in a seleniferous area. Am J Clin Nutr 53: 1288-1294, 1991.

106. Brätter P and Negretti de Brätter VE: Influence of high dietary selenium intake on the thyroid hormone level in human serum. J Trace Elem Med Biol 10: 163-166, 1996.

107. Fordyce FM, Zhan G, Green K and Liu X: Soil, grain and water chemistry in relation to human selenium-responsive diseases in Enshi District, China. Applied Geochemistry 15: 117-132, 2000. doi: 10.1016/S0883-2927(99)00035-9.

108.Zhu J, Wang N, Li S, Li L, Su H and Liu C: Distribution and transport of selenium in Yutangba, China: Impact of human activities. Sci Total Environ 392: 252-261, 2008.

109. Hira CK, Partal K and Dhillon KS: Dietary selenium intake by men and women in high and low selenium areas of Punjab. Public Health Nutr 7: 39-43, 2004.

110.Lemire M, Fillion M, Frenette B, Passos CJ, Guimarães JR, Barbosa F Jr and Mergler D: Selenium from dietary sources and motor functions in the Brazilian Amazon. Neurotoxicology 32: 944-953, 2011.
111. Lemire M, Philibert A, Fillion M, Passos CJ, Guimarães JR, Barbosa F Jr and Mergler D: No evidence of selenosis from a selenium-rich diet in the Brazilian Amazon. Environ Int 40: $128-136,2012$

112. Qin HB, Zhu JM, Liang L, Wang MS and Su H: The bioavailability of selenium and risk assessment for human selenium poisoning in high-Se areas, China. Environ Int 52: 66-74, 2013.

113. Martens IB, Cardoso BR, Hare DJ, Niedzwiecki MM, Lajolo FM, Martens A and Cozzolino SM: Selenium status in preschool children receiving a Brazil nut-enriched diet. Nutrition 31: 1339-1343, 2015.

114. Chawla R, Loomba R, Chaudhary RJ, Singh S and Dhillon KS: Impact of high selenium exposure on organ function and biochemical profile of the rural population living in seleniferous soils in Punjab, India. In: Global advance in selenium research from theory to application. CRC Press, Sao Paulo, pp93-94, 2015.

115. Yu SY, Zhu YJ and Li WG: Protective role of selenium against hepatitis B virus and primary liver cancer in Qidong. Biol Trace Elem Res 56: 117-124, 1997.

116. Yu SY, Zhu YJ, Li WG, Huang QS, Huang CZ, Zhang QN and Hou C: A preliminary report on the intervention trials of primary liver cancer in high-risk populations with nutritional supplementation of selenium in China. Biol Trace Elem Res 29: 289-294, 1991

117. Li WG: Preliminary observations on effect of selenium yeast on high risk populations with primary liver cancer. Zhonghua Yu Fang Yi Xue Za Zhi 26: 268-271, 1992 (In Chinese).

118. Li W, Zhu Y, Yan X, Zhang Q, Li X, Ni Z, Shen Z, Yao H and Zhu J: The prevention of primary liver cancer by selenium in high risk populations. Zhonghua Yu Fang Yi Xue Za Zhi 34: 336-338, 2000 (In Chinese).

119. Lotan Y, Goodman PJ, Youssef RF, Svatek RS, Shariat SF, Tangen CM, Thompson IM Jr and Klein EA: Evaluation of vitamin $\mathrm{E}$ and selenium supplementation for the prevention of bladder cancer in SWOG coordinated SELECT. J Urol 187: 2005-2010, 2012.

120. Klein EA, Thompson IM Jr, Tangen CM, Crowley JJ, Lucia MS, Goodman PJ, Minasian LM, Ford LG, Parnes HL, Gaziano JM, et al: Vitamin E and the risk of prostate cancer: The Selenium and Vitamin E Cancer Prevention Trial (SELECT). JAMA 306: 1549-1556, 2011.

121. Marshall JR, Tangen CM, Sakr WA, Wood DP Jr, Berry DL, Klein EA, Lippman SM, Parnes HL, Alberts DS, Jarrard DF, et al: Phase III trial of selenium to prevent prostate cancer in men with high-grade prostatic intraepithelial neoplasia: SWOG S9917. Cancer Prev Res (Phila) 4: 1761-1769, 2011. 